\title{
GEOMORPHOLOGY AND LAND USE/LAND COVER CHANGE DETECTION FOR EASTERN PART OF DESERT BACK OF MENOUFIA GOVERNORATE
}

\author{
A.H. El-Nahry (2), M.S. Amira ${ }^{(1)}$, F.E. Abu Agwa ${ }^{(1)}$ and T. K. Mahmoud ${ }^{(1)}$ \\ (1) Soil Sci. Dept., Fac. Agric. Menoufia univ. \\ (2) National Authority for Remote Sensing and Space Sciences (NARSS)
}

Received: Jan. 14, 2021

Accepted: Feb. 27, 2021

\begin{abstract}
The current investigation aims to identifying the geomorphological characteristics of the area east of desert part of Menoufia governorate west of Rashid Nile branch. Change detection of land use/land cover (LULC) classes between the years 2001 and 2020 are also carried out. The integration of Remote Sensing (RS) and Geographic Information System (GIS) techniques were used to perform this work.
\end{abstract}

The studied area is located between latitudes $30^{\circ} 5^{\prime}$ to $30^{\circ} 32^{\prime} \mathrm{N}$ and longitudes $30^{\circ} 30^{\prime}$ to $31^{\circ} \mathbf{0 0}$ ' E and covers about $1354 \mathrm{~km}^{2}$ or 322474 feddans. The interpretation of satellite image of the study area indicated that, there are three main identified geomorphic units including seven subunits in this area. These units are 1) Depressions: cover an area of $271 \mathrm{~km}^{2}$ or $\mathbf{6 4 5 3 0}$ feds (about $20.0 \%$ of the total studied area), 2) Sand Sheets: have 1022 $\mathrm{km}^{2}$ or 243354 feds $(75.3 \%)$, including Low- $(40.0 \%)$, Moderate- $(24.8 \%)$ and HighTerraces (10.5\%), and 3) Old Deltaic Revere Terraces: have $143 \mathrm{~km}^{2}$ or 34005 feds (10.5 $\%)$, including Low- (2.4\%), Moderate- (1.4 \%) and High-Terraces (0.9\%).

Binary encoding method was carried out based on classifying the Satellite images using decision tree classifier and statistical relative change detection to identify the relative change detection in (LULC) classes of agricultural land and barren area between 2001 and 2020 from the different Landsat images. The overall changes in LULC classes during this period indicated that, there is an increase in the cultivated area with $12.6 \%$ from the total studied area $\left(170.2 \mathrm{~km}^{2}\right.$ or 40535.6 fed) and shrunk in the baren land with $13.4 \%$ (181.2 $\mathrm{km}^{2}$ or $\left.43155.4 \mathrm{fed}\right)$.

Key words: RS, GIS, geomorphic unit, land use/land cover Change detection.

\section{INTRODUCTION}

The world is facing a rapid urbanization that results in densely urbanized agglomerations, and sprawls on the agricultural lands. As a developing country, Egypt with a total area of about 1 million $\mathrm{km}^{2}$ is challenged by this problem. In the center of Egypt's plateau lies the Nile Delta, surrounded by urban agglomerations that is interrupting the agricultural land close to the Nile River banks. The agricultural land total area represents $3.3 \%$ of the country's total area (Alfiky et al., 2012). The area of these agricultural lands has decayed due to urban challenges and issues. The rapid urbanization and proliferating number of populations in Egypt has led to the loss of the agricultural land in the Nile Valley. In the last two decades, the urbanization percentage in the Nile Delta region, according to Shalaby (2012), increased by roughly the treble percentage (Fig. 1). This rapid urbanization resulted in a loss of 300,000 acres of agricultural land during the period 1952 till 2002 (The World Bank, 2007). The fragmentation of the agricultural land has resulted in loss of agricultural plots: as the land owners built on their own private plots as an answer to housing needs. However, the 
adopted policies of land reclamation was an attempt to compensate for that loss of agricultural land. As an answer to this rapid urbanization, new settlements are being established to conceive the proliferating number of populations. However, the establishment and development of such new development does not take into consideration the loss of agriculture. This amplifies the pressure of food scarcity on the poor, and locates food production sources away from their consumption points. In return, this leads to magnifying the problem of increased fuel consumption, losing connection to healthy food production, and food scarcity. Another attempt to compensate for the loss of the agricultural land: was through the integration of agricultural lands into the planning of the new established urban settlements. The establishment of new satellite cities with agricultural peripheries in the form of reclaimed desert lands was one of these attempts that integrated agriculture into the urbanization of desert lands. Those reclaimed desert lands are in proximity or an extension to existing agricultural lands in the Nile Delta, as in the case of El Sadat City (Noseir, 2014).

Land use/land cover (LULC) change detection is an important process for monitoring and managing natural resources and urban development because it provides quantitative analysis of spatial distribution in the area of interest (Mahmoodzadeh, 2007).

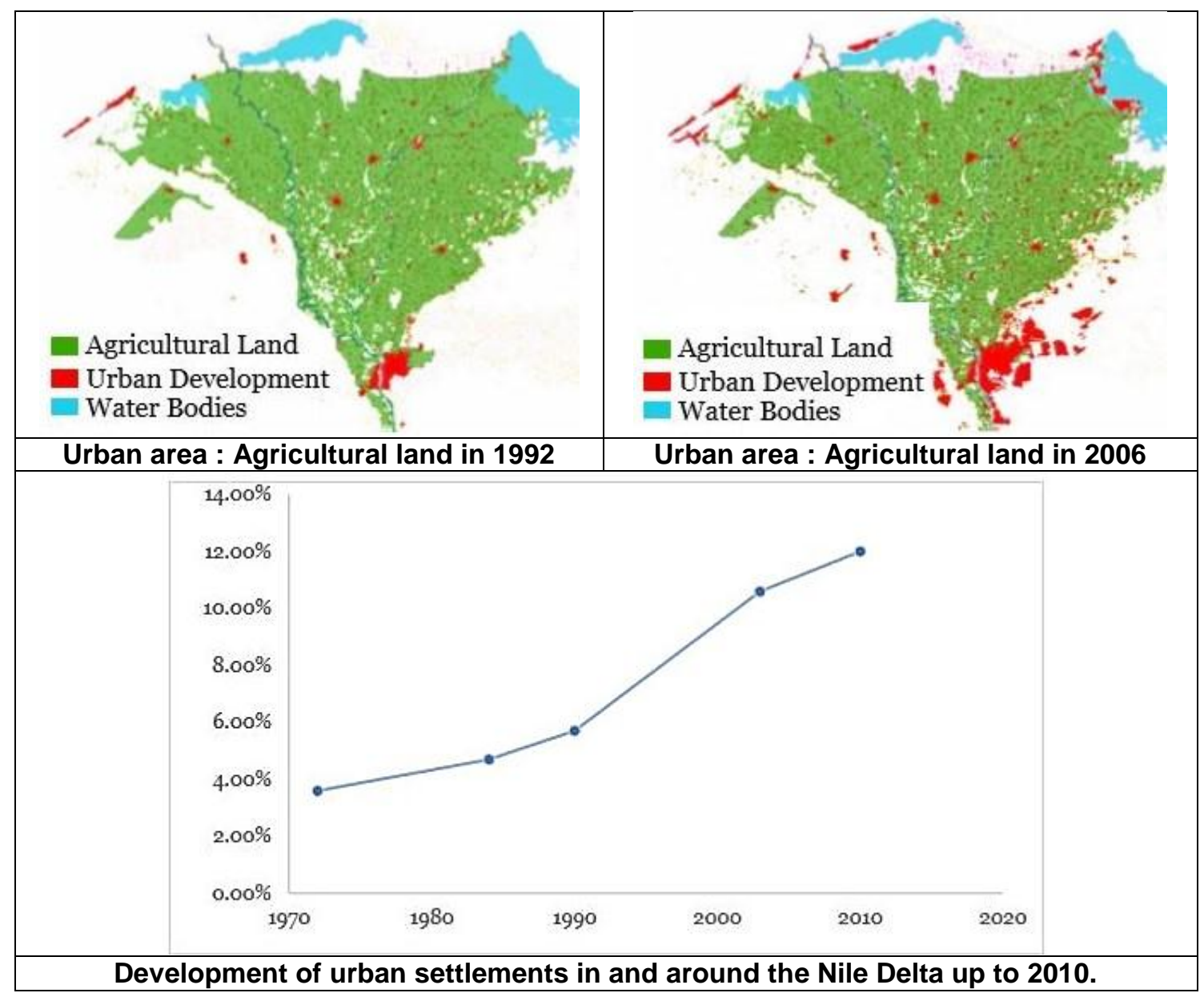


Fig. (1): Urban/Agricultural land cahnge detection in and around the Nile Delta between 1992 and 2010. (Shalaby, 2012).

El-Sadat area that located at the west of Nile Delta in the north western desert of Egypt are considered one from the important fringe's areas of the Delta for horizontal expansion of sustainable agricultural development in Egypt. It was annexed to Menoufia governorate west of the Rashid branch which increases the governorate area from 1532 to $2543 \mathrm{Km}^{2}$.

The identification of geomorphological characteristics is from the important initial stages for studying any areas. This area, generally, formed of some low-lying hills that received special attention due to their reasonably good groundwater resources. Geomorphologically, this area is divided into four units; young alluvial plains, old alluvial plains, conglomerates and sand dunes (Dawoud et al., 2005). Remote sensing (RS) is now recognized as an important tool in monitoring and managing natural resources (Lillesand and Kiefer, 2007). They added that, RS technique is one of the important methods that used for soil survey, mapping and environmental investigation. ESRI (2003) stated that, geographic information system (GIS) is a system for the management, analysis, and displaying geographic information, which is represented by a series of geographic datasets that model geography using simple, generic data structures.

The aim of this work is to identifying the geomorphological characteristics for the eastern part of the desert area of Menoufia governorate. Also, LULC change detection in this area over 20 years is studied and mapped. The integration of RS and GIS) techniques was used to perform all results and produce the spatial digital maps of this work.

\section{MATERIALS AND METHODS}

\section{Study area}

The study area is located at the east of desert part of Menoufia governorate west of Rashid Nile branch, between latitudes $30^{\circ} 5^{\prime}$ to $30^{\circ} 32^{\prime} \mathrm{N}$ and longitudes $30^{\circ} 30^{\prime}$ to $31^{\circ} 00^{\prime} \mathrm{E}(\mathrm{Fig}, 2)$ having an area of about 1354 km $^{2}$ (322474 feddan). 


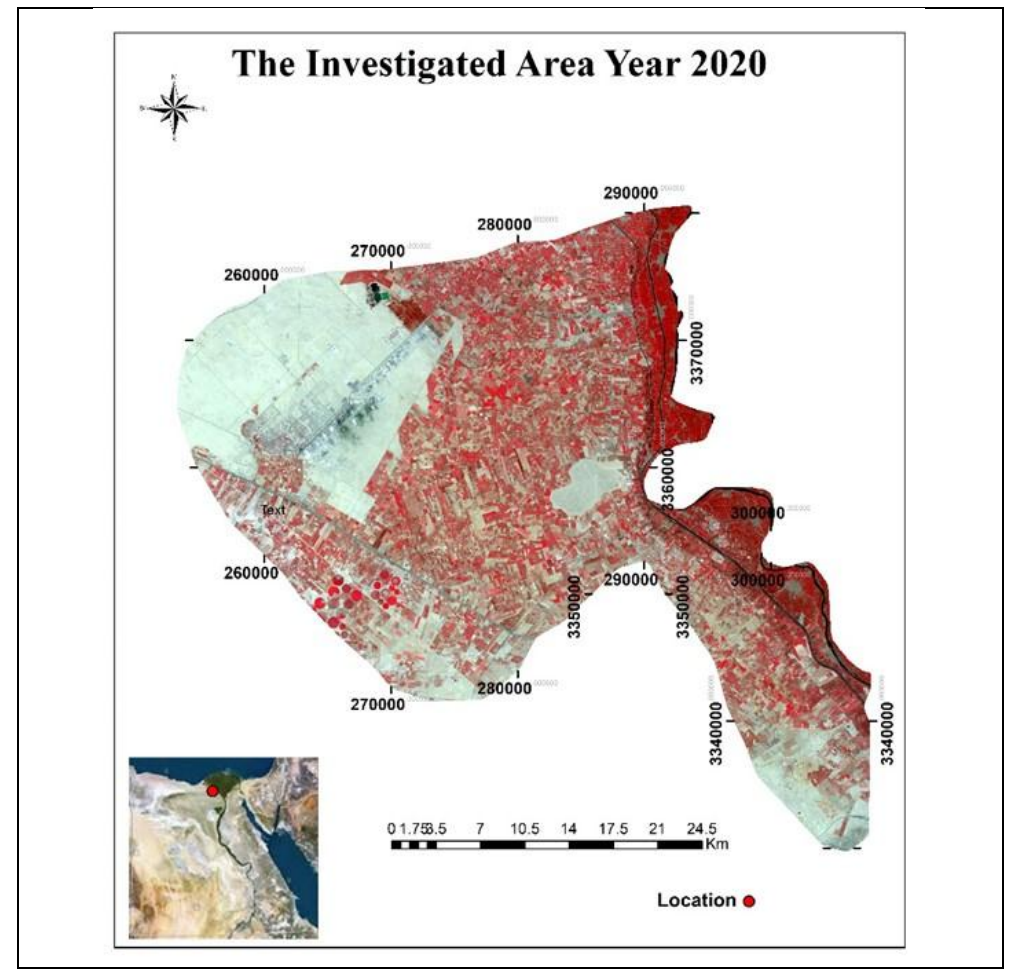

Fig (2): Map of the study area.

\section{Producing geomorphic map}

The digital elevation model (DEM) of the study area was extracted from the Shuttle Radar Topography Mission (SRTM) and a topographic map with a scale of 1:25,000 covering the study area using Arc-GIS 10.4 software (ESRI, 2003). The Landsat 8 (path 179 / row 39) image acquired in 2018 and SRTM data were processed in ENVI 5.3 software (ITT, 2012) to identify the geomorphic units and landforms of the studied area according to the approach developed by Dobos et al. (2002). The map legend was designed according to Zinck and Valenzuela (1990). ArcMap 10.7 software was used to display and produce geomorphic map with help of field observations (ESRI, 2018).

\section{Land use/land cover (LULC) change detection}

Change detection is RS technique manipulated for determining, identifying and monitoring the changes occurring within the LULC of the earth's surface in the area under consideration. It embraces applying digital image processing and classification for multi-temporal remotely sensed imageries for the study area. This followed by field observation and ground truth data collected from the same considered area for conducting accuracy assessment as an end point. The classification of LULC was performed using detection tree classification.

The goal of image classification is to automatically classify all pixels of multi spectral image into one or several classes or themes. The spectral reflectance characteristics of different features manifest different combination of digital values (commonly known as spectral signatures). Based on these spectral signatures, a new output image is created having specific number of categories or clusters. These categories data may then be used to produce thematic maps. Decision tree classifier with the help of binary encoding method in ENVI 5.6 software was used to match the change detection according to Mazer et al. (1988). Decision tree is one of the 
predictive modeling approaches used in statistics. Change detection statistics is used to collected the statistics of the decision tree classes. Statistics could be presented in pixels, areas and percentage. Decision tree classifier was used to classify both ETM image that acquired year 2001 and Landsat 8.0 image that acquired year 2020.

\section{RESULTUS AND DISCUSSION Geomorphology}

Based on the satellite image treating, processing and interpretation with the aid of produced Digital Elevation Model (DEM), topographic maps and field observations, the integration of RS and GIS was used to identify the geomorphic and landform units of the study area. Produced DEM map of the study area presented in Fig. (3) indicated that, the elevation of this area is varied between 7 $m$ above sea level (a.s.l.) at the north east of the study area and increased gradually to $171 \mathrm{~m}$ a.s.l. at the south of the area.

The produced detailed geomorphic units' map presented in Fig. (4) indicated that, the studied area has three main geomorphic units divided into seven subunits as shown in Table (1).

These detailed geomorphic units and subunits presented in Fig. (4) and Table (1) are:

1. Depressions: Cover an area of $\mathbf{2 7 1} \mathbf{~ k m 2}$ $(64530 \mathrm{fed})$, which occupied about $20.0 \%$ of the total studied area.

2. Sand Sheets: covers 1022 km $^{2}(243354$ fed), $75.3 \%$ having three subunits namely:

a) Low sand sheet: has $542 \mathrm{~km}^{2}(129080$ fed), $40.0 \%$.

b) Moderate sand sheet: has $337 \mathbf{k m}^{2}$ (80269 fed), $24.8 \%$.

c) High sand sheet: has $143 \mathrm{~km}^{2}(34005$ fed), $10.5 \%$.

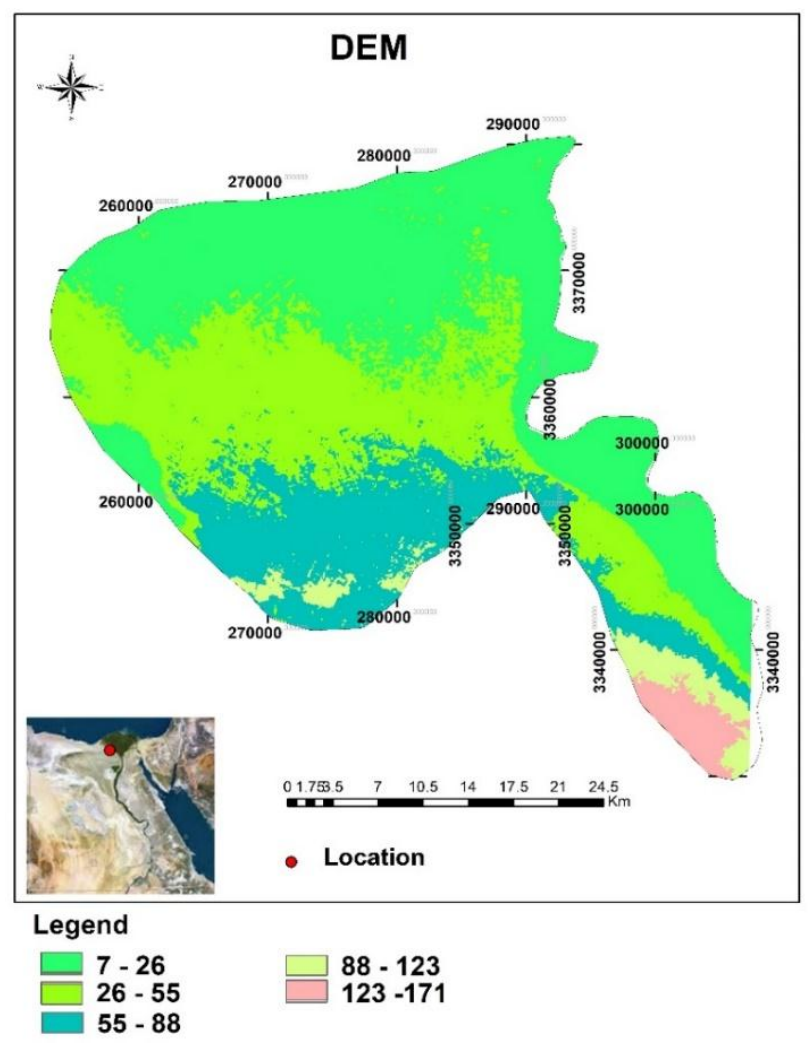

Fig. (3): DEM map of the study area. 


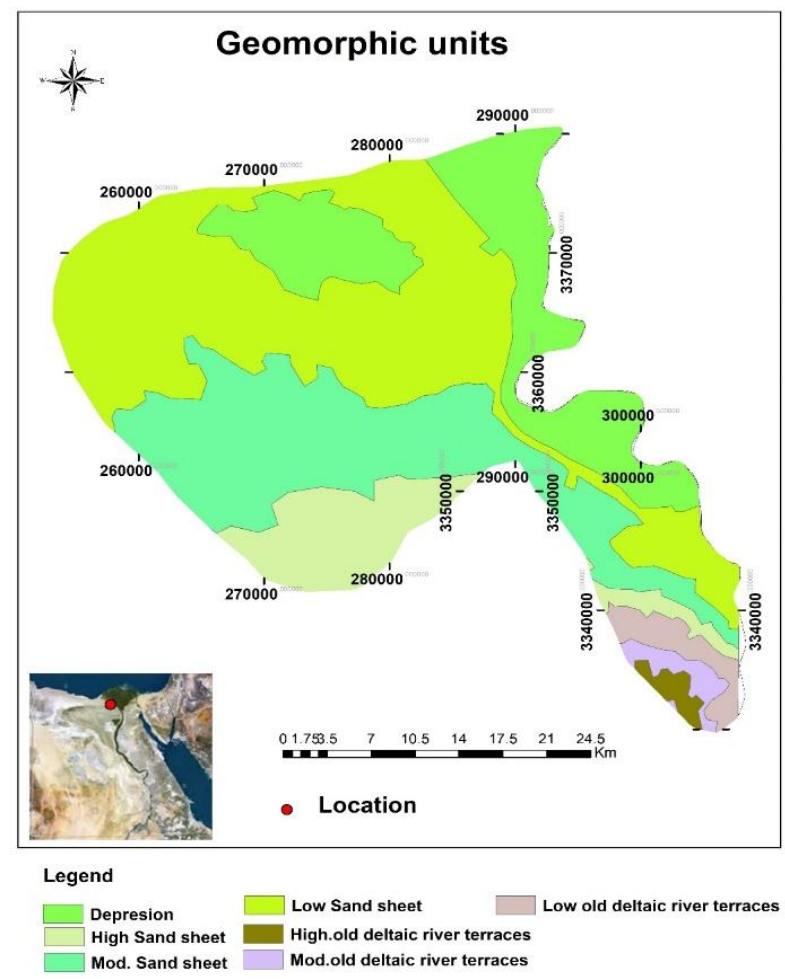

Fig (4): Geomorphic map of the study area.

Table (1): Detailed geomorphic units of the study area.

\begin{tabular}{|c|c|c|c|c|}
\hline Geomorphic units & Land forms & $\begin{array}{l}\text { Area } \\
\left(\mathrm{km}^{2}\right)\end{array}$ & Area (fed) & $\begin{array}{c}\% \\
\text { from total } \\
\text { area }\end{array}$ \\
\hline Depressions & Depressions & 271 & 64530 & $20.0 \%$ \\
\hline \multirow{4}{*}{ Sand sheet } & Low sand sheet & 542 & 129080 & $40.0 \%$ \\
\hline & Mod. sand sheet & 337 & 80269 & $24.8 \%$ \\
\hline & High sand sheet & 143 & 34005 & $10.5 \%$ \\
\hline & Total & 1022 & 243354 & $75.3 \%$ \\
\hline \multirow{4}{*}{$\begin{array}{l}\text { Old deltaic river } \\
\text { terrace }\end{array}$} & $\begin{array}{c}\text { Low old deltaic river } \\
\text { terrace }\end{array}$ & 31 & 7473 & $2.4 \%$ \\
\hline & $\begin{array}{c}\text { Mod. old deltaic river } \\
\text { terrace }\end{array}$ & 18 & 4177 & $1.4 \%$ \\
\hline & $\begin{array}{c}\text { High old deltaic river } \\
\text { terrace }\end{array}$ & 12 & 2940 & $0.9 \%$ \\
\hline & Total & 61 & 14590 & $4.7 \%$ \\
\hline \multicolumn{2}{|c|}{ Total } & 1354 & 322474 & $100 \%$ \\
\hline
\end{tabular}

3. Old deltaic river terraces: cover $61 \mathrm{~km} 2$ (14590 fed), $4.7 \%$, having three subunits namely:

a) Low Old deltaic river terrace: has $\mathbf{3 1}$ $\mathrm{km}^{2}$ (7473 fed), $2.4 \%$. b) Moderate old deltaic river terrace: has $18 \mathrm{~km}^{2}$ (4177 fed), $1.4 \%$.

c) High old deltaic river terrace: has 12 $\mathbf{k m}^{2}$ (2940 fed), $0.9 \%$. 


\section{Land use/Land cover change detection}

Change Detection provides a way to compare imagery collected over the same area at different times and highlight features that have changed. There are two forms of change detection: (absolute and relative). Absolute change detection focusses specifically on what has been changed (e.g., barren area to agricultural land). Relative change detection with binary encoding method shows the statistics of the decision tree classes. Relative change detection was adopted for the current study in two steps namely, 1) Classifying images using decision tree classifier for getting the best classification results and 2) Using Relative change detection statistically.

1) Decision tree classifier: The decision tree is a type of multistage classifier that can be applied to a single image or a stack of images. It is made up of a series of binary decisions that are used to determine the correct category for each pixel. The decisions were based on any available characteristic of the dataset. In the current study, decision tree classifier was used to classify both Enhanced Thematic Mapper (ETM) image that acquired year 2001 and Landsat 8.0 image that acquired year 2020. Three algorithms with different band combination were used to match wavelengths of ETM+ and Landsat 8.0. The classification resulted into four classes i.e., cultivation, wetland, barren areas and others as shown in Figs (5 and 6).

2) Statistical assessing of relative change detection: This is to assess the relative changes in LULC classes between the period from 2001 to 2020 based on the accounting of the pixels representing each of these classes in the two studied years. By transformation the numbers of pixels for each of LULC classes into $\mathrm{km}^{2}$ or feddan, the results given In Table (2) and Fig (7) indicated that, the agricultural land class grew by 170.2 $\mathrm{km}^{2}$ or 40535.6 fed (+ $12.6 \%$ from the total studied area) and the barren area shrunk by $181.2 \mathrm{~km}^{2}$ or 43155.4 fed (13.4\%).

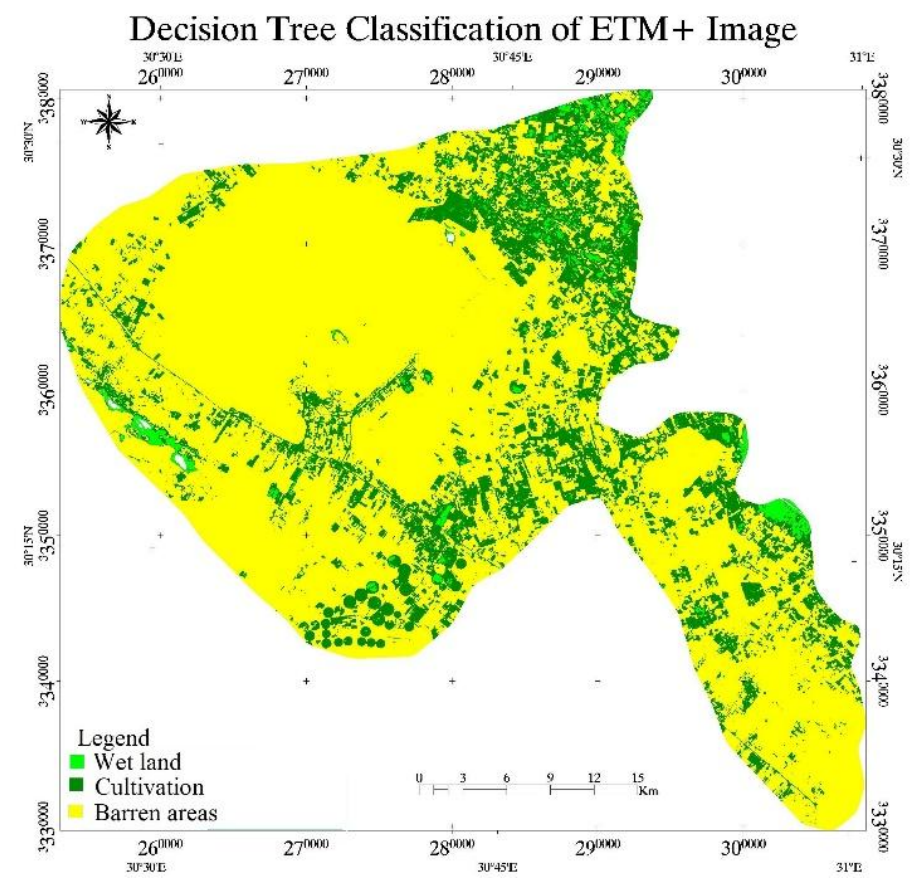


A.H. El-Nahry, et al.,

Fig (5): Decision tree classification of $\mathrm{ETM}^{+}$image (2001).

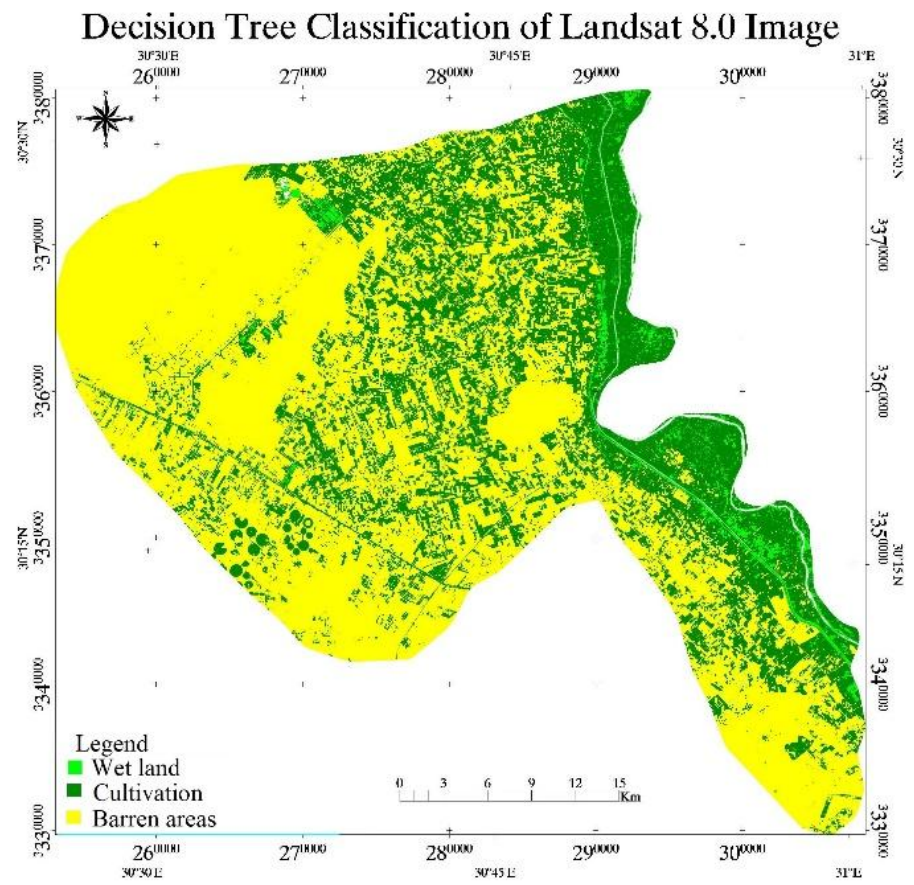

Fig (6): Decision tree classification of Landsat 8 image (2020).

Table (2): Changes of LULC area from 2001 to 2020.

\begin{tabular}{|c|c|c|c|c|c|c|c|c|c|}
\hline \multirow{2}{*}{$\begin{array}{c}\text { LULC } \\
\text { classes }\end{array}$} & \multicolumn{5}{|c|}{ Area of each class in } & \multicolumn{3}{c|}{ Area changes } \\
\cline { 2 - 10 } & \multicolumn{3}{|c|}{2001} & $\mathrm{Km}^{2}$ & Fed & $\%$ \\
\cline { 2 - 11 } & $\mathrm{Km}^{2}$ & Fed & $\%$ & $\mathrm{Km}^{2}$ & Fed & $\%$ & & & \\
\hline Agriculture & 282.5 & 67281.5 & 20.8 & 452.7 & 107817.1 & 33.4 & +170.2 & +40535.6 & +12.6 \\
\hline Barren land & 891.2 & 212252.3 & 65.8 & 710.0 & 169096.9 & 52.4 & -181.2 & -43155.4 & -13.4 \\
\hline Wet land & 25.3 & 6025.5 & 1.9 & 30.0 & 7144.9 & 2.3 & +4.7 & +1119.3 & +0.4 \\
\hline Others & 155.0 & 36915.5 & 11.5 & 161.3 & 38415.9 & 11.9 & +6.3 & +1500.4 & +0.4 \\
\hline
\end{tabular}




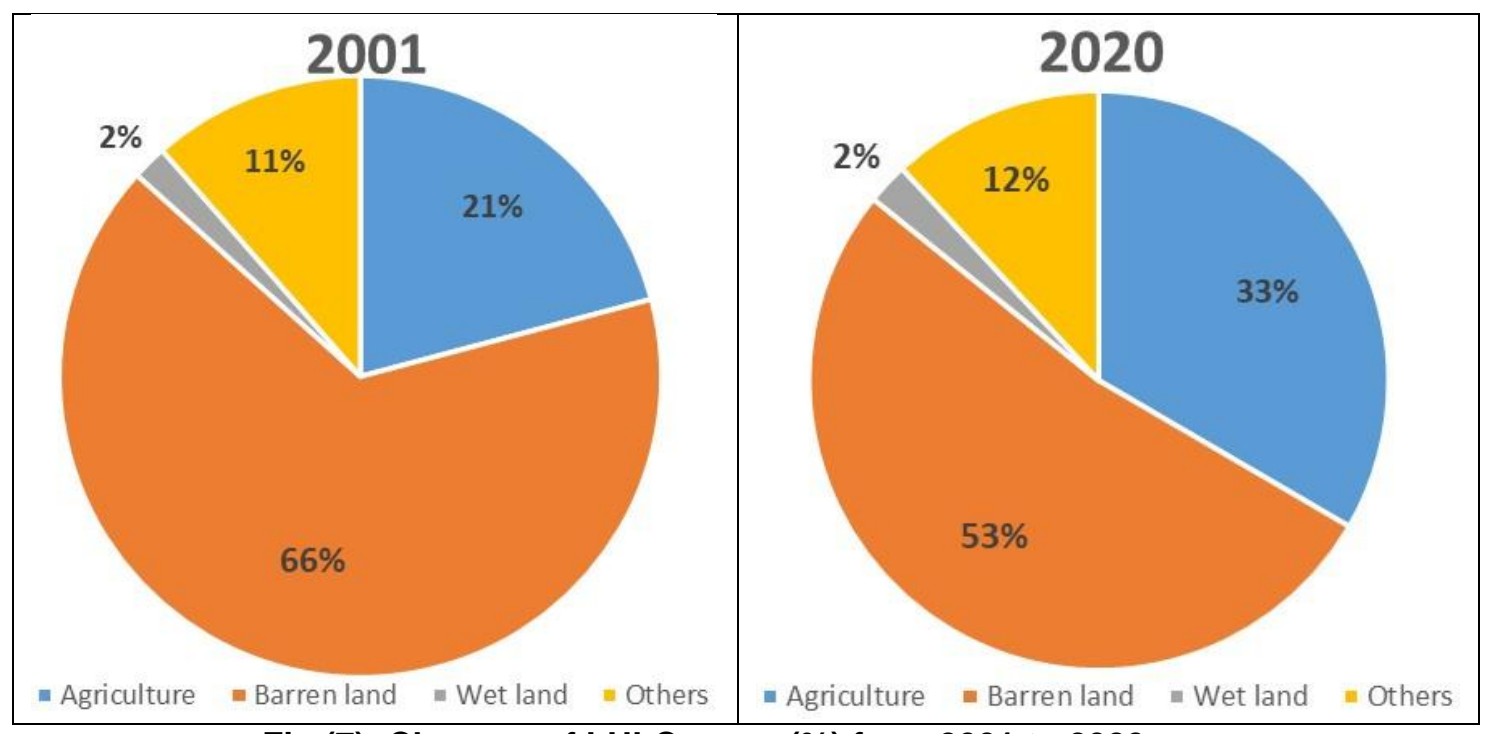

Fig (7): Changes of LULC areas (\%) from 2001 to 2020.

\section{REFERANCES}

Alfiky, A., G. Kaule and M. Salheen (2012). Agricultural fragmentation of the Nile Delta; a modeling approach to measuring agricultural land deterioration in Egyptian Nile Delta. Procedia Environmental Sciences 14: 79-97.

Dawoud, M.A., M.M. Darwish and M.M. ElKady (2005). GIS-based groundwater management model for Western Nile Delta. Water Resources. Manag. 19: 585-604.

Dobos, E., B. Norman, W. Bruee, M. Luca, J. Chris and M. Erika (2002). The use of DEM and satellite images for regional scale soil database. Proceedings of the 17th World Congress of Soil Science, Bangkok.

ESRI "Environmental Systems Research Institute" (2003). Using ArcGIS geostatistical analyst. Environmental Systems Research Institute (ESRI) Press, Redlands, California.

ESRI (Environmental Systems Research Institute) (2018). Arc Map Version 10.7 User Manual. ESRI, 380 New York Street, Redlands, California, 923738100 , USA.
ITT "International Telephone \& Telegraph" (2012). ITT corporation ENVI 5 software, 1133 Westchester Avenue, White Plains, NY 10604, USA.

Lillesand, T. M. and R. W. Kiefer (2007). Remote Sensing and Image Interpretation. 5th ed. Paper back. John Wiley, New York, USA.

Mahmoodzadeh, H. (2007). Digital change detection using remotely sensed data for monitoring green space destruction in Tabriz. Int. J. Environ. Res., 1(1): 35 - 41.

Mazer, A. S., M. Martin, M. Lee and J. Solomon (1988). "Image Processing Software for Imaging Spectrometry Analysis." Remote Sensing of Environment 24 (1): 201-210.

Noseir, Dina M.A. (2014). Assessing the potentials of multi-functional urban agriculture in Egypt, towards cultivating the new urban settlements "The case of Al Sadat City", MSc. Thesis, Ain Shams Univ.

Shalaby, A. (2012). Assessment of urban sprawl impact on the agricultural land in the Nile Delta of Egypt using remote sensing and digital soil map., International Journal of Environment and Sciences 1 (4): 253-262. 
A.H. El-Nahry, et al.,

The World Bank (2007). Tackling the Shelter Challenge of Cities: Thinking it Through Together. Cairo, Egypt.
Zinck, J.A. and C.R. Valenzuela (1990). Soil Geographic Database: Structure and Application Examples. ITC journal, 3: 270.

جيومورفولوجيا ومدى التغير في استخدام وكساء أراضي المنطقة الشرقية للظهيز الصحراوي لمحافظة المنوفية

علاء الدين حسن محمد النهري(؟)، محمد سمير عراقي عميرة(')، فوزي الشاذلي أبو عجوة(')،

$$
\text { طارق خطاب محمود }
$$

(1) (1) قسم علوم الأراضي - كلية الزراعة - جامعة المنوفية

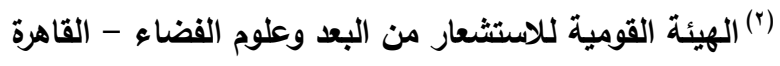

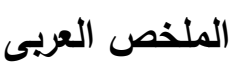

أجري هذا البحث بهدف التعرف على الخصائص الجيومرفولوجية للمنطقة شرق الظهير الصحراوي لمحافظة المنوفية،

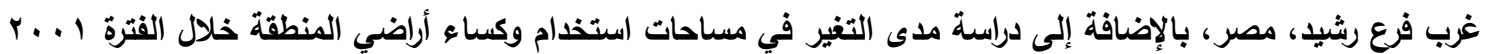




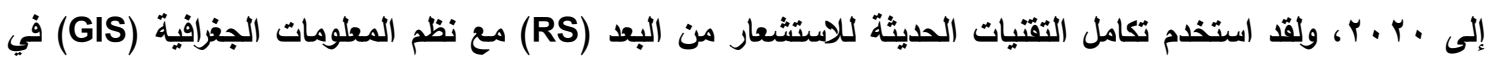

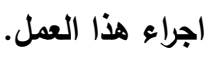

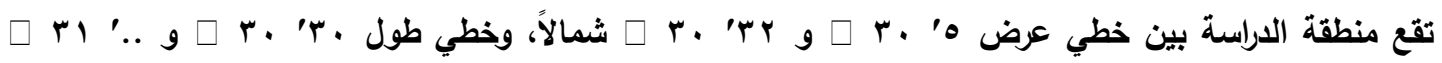

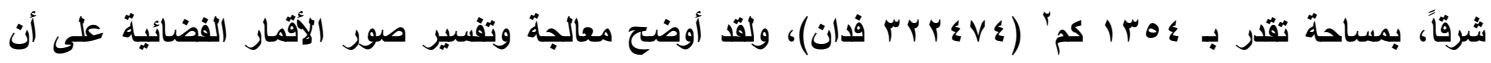

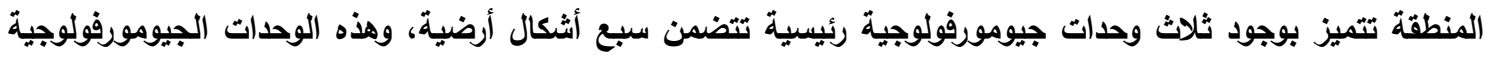

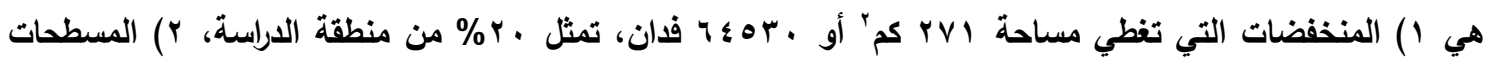

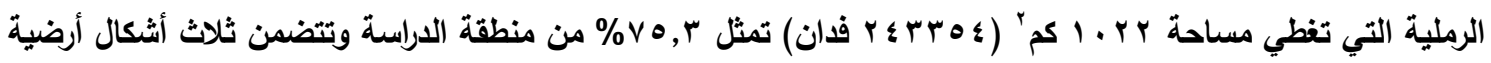

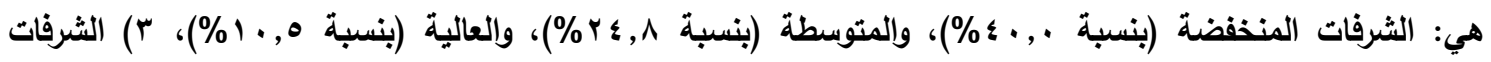

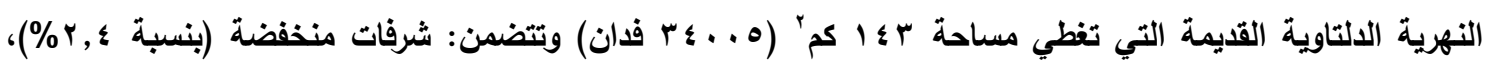
ومتوسطة (بنسبة \& , 1\%)، ومرتفعة (بنسبة 9 . . \%\%). وياستخام نظام التحول الرقمي المزدوج الذي يعتمد على أسلوبي التقسيم الثجري والتحليليل الاحصائي النسبي في دراسة وتحليل صور الأقمار الصناعية لحساب مدى التغير في مساحات استخدام وكساء أراضي المنطقة بين عامي

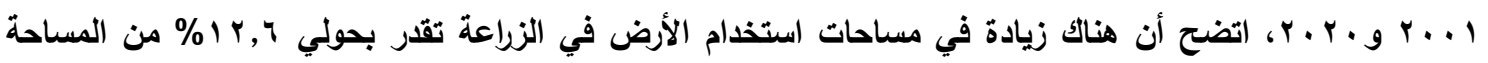

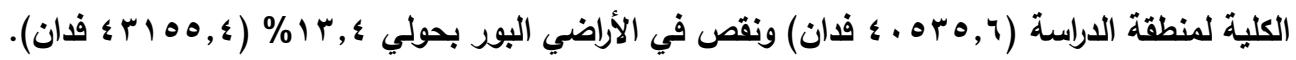

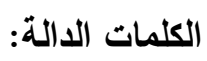
الاستشعار من البع، نظم المعلومات الجغرافية، الوحدات الجيومورفولوجية، التغير في استخام وكساء الأراضي. 